\title{
Serum Uric Acid Levels among Patients who Died in Recent Year due to Heart Failure with Reduced Ejection Fraction
}

\author{
Isa Ardahanli ${ }^{1}$ and Mehmet Celik ${ }^{2}$ \\ ${ }^{1}$ Department of Cardiology, Bilecik State Hospital, Bilecik, Turkey \\ ${ }^{2}$ Department of Endocrinology and Metabolism, Faculty of Medicine, Trakya University, Edirne, Turkey
}

\begin{abstract}
Objective: To examine the relationship of uric acid levels in the last one year with exitus due to heart failure (HF) with clinical and demographic data of patients.

Study Design: Cross-sectional, descriptive study.

Place and Duration of Study: Bilecik State Hospital, Bilecik, Turkey, from January 2019 to January 2020.

Methodology: The files of 90 people who had exitus due to HF were scanned retrospectively. Demographic data and echocardiography results were recorded. Serum uric acid levels were noted in the $2^{\text {nd }}$ month, $6^{\text {th }}$ month, and $12^{\text {th }}$ month by taking the baseline in the last year before exitus. Mean repeated measurements of uric acid levels that changed over time in patients were compared with ANOVA variance analysis. $\mathrm{P}<0.05$ were accepted as statistically significant.

Results: The mean of the left ventricular ejection fraction (LVEF) of the patients was $35.6 \pm 6.6 \%$. Mean serum uric acid levels of the patients for one year before excitus were $5.6 \pm 2.2 \mathrm{mg} / \mathrm{dL}$ (baseline), $6.1 \pm 2.3 \mathrm{mg} / \mathrm{dL}\left(2^{\text {th }} \mathrm{month}\right), 7.1 \pm 2.6 \mathrm{mg} / \mathrm{dL}\left(6^{\text {th }}\right.$ month), $8.5 \pm 3.0 \mathrm{mg} / \mathrm{dL}\left(12^{\text {th }}\right.$ month) respectively. There was a statistically significant difference between the basal uric acid mean with the $6^{\text {th }}$ and $12^{\text {th }}$ month uric acid levels both $p<0.001$. Age and LVEF were not significantly associated with the uric acid increase over time ( $p=0.250$ and $p=0.327$, respectively) but were statistically different according to gender $(p=0.036)$.
\end{abstract}

Conclusion: In heart failure with reduced ejection fraction (HFrEF), the uric acid level increases progressively towards the last periods before exitus. This increase is more pronounced in men.

Key Words: Heart failure, Serum uric acid levels, Prognosis, Gender.

How to cite this article: Ardahanli I, Celik M. Serum Uric Acid Levels among Patients who Died in Recent Year due to Heart Failure with Reduced Ejection Fraction. J Coll Physicians Surg Pak 2020; 30(08):780-784.

\section{INTRODUCTION}

Heart failure (HF) is a preventable clinical syndrome with cardiac structural or functional disorders. ${ }^{1} \mathrm{HF}$ is classified into 3 groups according to pump dysfunction. It is classified as HF with reduced ejection fraction ( $\mathrm{HFrEF}$ ) ( $\mathrm{EF}<\% 40)$, HF with mid-range ejection fraction (HFmEF, EF \% 40 to 49 ), and HF preserved ejection fraction (HFpEF, EF \% >50). ${ }^{1}$ To estimate the prognosis of $\mathrm{HF}$, It can be obtained from easily available data such as age, etiology, New York Heart Society (NYHA) symptom classification, left ventricular ejection fraction (LVEF), concomitant diseases (kidney dysfunction, diabetes, anemia, thyroid dysfunctions, hyperuricemia) and plasma natriuretic peptide concentrations.

Correspondence to: Dr. Isa Ardahanli, Department of Cardiology, Bilecik State Hospital, Bilecik, Turkey

E-mail: isaardahanli@gmail.com

Received: May 05, 2020; Revised: August 02, 2020;

Accepted: August 13, 2020

DOI: https://doi.org/10.29271/jcpsp.2020.08.780
However, many variables can provide information about the prognosis of the diseases. ${ }^{2-4} \mathrm{Uric}$ acid is the end product that occurs as a result of purine metabolism in humans, and high uric acid levels in coronary artery disease and many cardiovascular diseases have been reported to beassociated with poor results. ${ }^{5,6}$ Hyperuricemia may occur or worsen as a result of diuretic therapy in HF. This effect is more pronounced in patients with systolic dysfunction or reduced LVEF.

In recent years, although many studies have argued that increased serum uric acid levels are associated with the risk of cardiovascular disease, this is still controversial, since it has not been fully clarified whether the height of uric acid causes cardiovascular diseases or increases as a result of the disease. ${ }^{7}$

The aim of this study was to examine the relationship of uric acid levels in the last one year with exitus due to heart failure with clinical and demographic data in patients.

\section{METHODOLOGY}

The study was conducted by scanning archives from January 2019 to January 2020 in Bilecik State Hospital. 
Table I: Evaluation of serum uric acid levels by repeated variance analysis over time.

\begin{tabular}{|c|c|c|c|c|c|}
\hline \multicolumn{2}{|l|}{ Uric acid levels } & \multirow{2}{*}{$\begin{array}{c}\text { Mean difference }(\mathrm{I}-\mathrm{J}) \\
0.505\end{array}$} & \multirow{2}{*}{$\begin{array}{c}\text { Std. error } \\
.188\end{array}$} & \multirow{2}{*}{$\frac{p \text {-value }}{0.052}$} & \multirow{2}{*}{$\begin{array}{c}\text { 95\% Confidence interval for } \\
\text { difference }\end{array}$} \\
\hline Second month & Baseline & & & & \\
\hline \multirow{2}{*}{ Sixth month } & Baseline & $1.468^{*}$ & .248 & $<0.001$ & $0.800-2.136$ \\
\hline & $2^{\text {nd }}$ month & 0.963* & .264 & 0.003 & $0.250-1.677$ \\
\hline \multirow{3}{*}{ Twelfth month } & Baseline & $2.875^{*}$ & .320 & $<0.001$ & $2.013-3.738$ \\
\hline & $2^{\text {nd }}$ month & $2.370 *$ & .321 & $<0.001$ & $1.503-3.237$ \\
\hline & $6^{\text {th }}$ month & $1.407 *$ & .231 & $<0.001$ & $0.785-2.029$ \\
\hline
\end{tabular}

Table II: The relationship of serum uric acid levels over time with clinical and demographic data.

\begin{tabular}{|c|c|c|c|c|c|}
\hline Source & Type III sum of squares & Mean square & $\mathrm{F}$ & $P$ & Partial Eta squared \\
\hline Time & 53.314 & 24.074 & 5.771 & 0.003 & 0.063 \\
\hline Time *Age & 12.873 & 5.813 & 1.393 & 0.250 & 0.016 \\
\hline Time *LVEF\% & 10.488 & 4.736 & 1.135 & 0.327 & 0.013 \\
\hline Time *Gender & 30.167 & 13.621 & 3.265 & 0.036 & 0.037 \\
\hline
\end{tabular}

Table III: Serum uric acid levels over time by gender.

\begin{tabular}{|l|c|c|}
\hline & Male (n:47) & Female (n:43) \\
\hline Uric Acid 1 $1^{\text {st }}$ month (mean) & $5.143 \pm 1.70$ & $6.166 \pm 2.63$ \\
\hline Uric Acid 2 ${ }^{\text {nd }}$ month (mean) & $5.617 \pm 1.65$ & $6.705 \pm 2.72$ \\
\hline Uric Acid 6 ${ }^{\text {th }}$ month (mean) & $6.813 \pm 2.15$ & $7.414 \pm 3.01$ \\
\hline Uric Acid 12 ${ }^{\text {th }}$ month (mean) & $8.688 \pm 2.78$ & $8.309 \pm 3.15$ \\
\hline
\end{tabular}

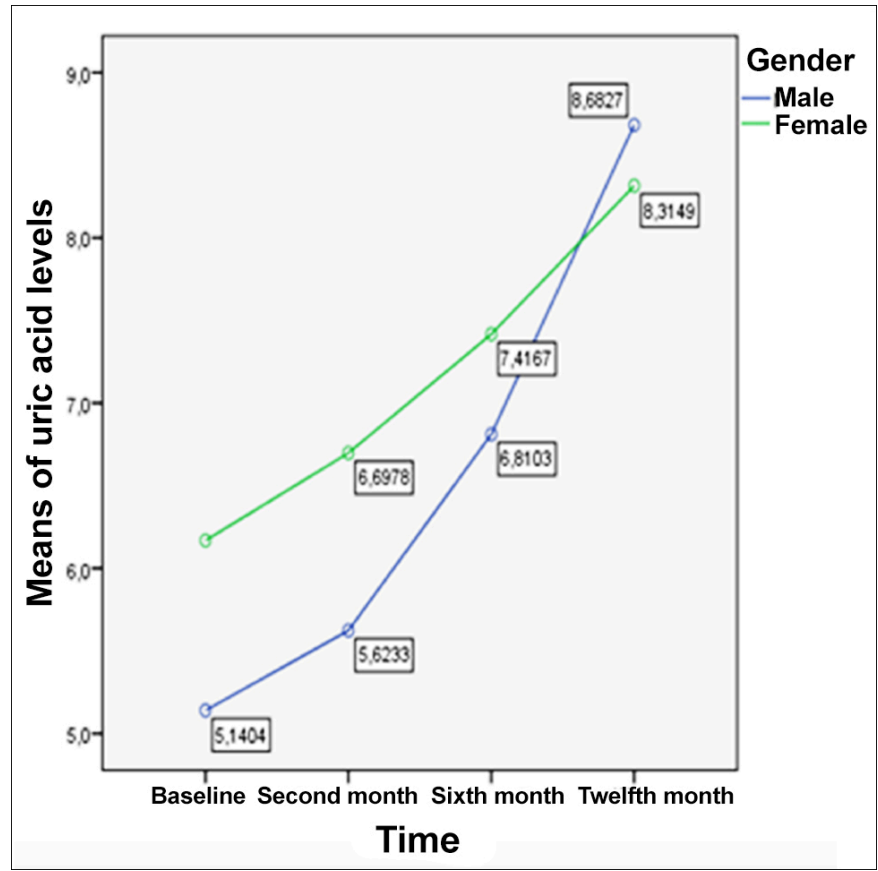

Figure 1: The graph of the change of serum uric acid levels in one year without exitus.

Records of 90 subjects, who had exitus due to heart failure with reduced ejection fraction (HFrEF), were evaluated retrospectively. Demographic data (age, gender) and echocardiographic evaluation results of the patients were recorded. Serum uric acid levels were retrospectively screened for the second month, sixth month, and twelfth month based on the initial baseline of the last year. Hyperuricemia was defined as uric acid levels of $>6 \mathrm{mg} / \mathrm{dL}$ in women and $>7 \mathrm{mg} / \mathrm{dL}$ in men. The values measured by the modified Simpson method were used for the LVEF measurement. Patients with LVEF $\leq 40 \%$ were included in the study (LVEF remained stable in the past one year according to NYHA. Patients with malignancy, those treated for gout, patients with uncontrolled diabetes mellitus, pregnant women, patients with hemolytic anemia, hemodialysis treatment, those who had a heart transplant and history of moderate or severe valvular heart disease were excluded from the study.

Statistical package for the social sciences (SPSS) (Version 22.0. Armonk, NY, IBM Corp., USA) programme was used for statistical analysis. The characteristics of patients were evaluated with descriptive analysis. The mean of uric acid levels varying over time in patients were repeated with variance analysis ANOVA. The globality conjecture was evaluated by the Mauchly test in SPSS. Since the $p$ value was $<0.05$ in Mauchly's test, the Greenhouse and Geisser correction was preferred for the $F$ value. The Bonferroni method was used to examine the relationship between variables; and to investigate the relationship between uric acid levels measured at different times in this study. $P$ values below 0.05 were accepted as statistically significant.

\section{RESULTS}

The average age of the patients included in the study was $76.6 \pm 8$ years. Forty-three $(47.8 \%)$ of the patients were 
females and 47 (52.2\%) were males. The mean LVEF in the study group was $35.6 \pm 6.6 \%$. The mean 1 -year serum uric acid levels before the exitus were basal $=5.6 \pm 2.2 \mathrm{mg} / \mathrm{dL}$, second month $=6.1 \pm 2.3 \mathrm{mg} / \mathrm{dL}$, sixth month $=7.1 \pm 2.6$ $\mathrm{mg} / \mathrm{dL}$, twelfth month $=8.5 \pm 3.0 \mathrm{mg} / \mathrm{dL}$.

As a result of repeated measurement variance analysis, considering the change of uric acid over time, there was no statistical difference between basal uric acid levels and the second-month uric acid levels $(p=0.052)$. However, there was a statistically significant difference between the basal uric acid levels and the 6th and $12^{\text {th }}$ month uric acid levels ( $p$ $<0.001, p<0.001$, respectively). Uric acid levels were observed to increase over time and the highest mean was found to be in the 12th month (Table I).

By One-Way variance analysis, the relationship between age, gender, and LVEF were evaluated with the change of uric acid levels over time. While the increase in uric acid overtime was not statistically correlated with age and LVEF ( $p=0.250$, and $p=0.327$, respectively). There were statistically differences according to gender $(p=0.036$, Table II).

It was observed that while the level of uric acid was higher in women at the beginning, the level of uric acid was higher in men before excitus than in women (Figure 1 ).

When the change of uric acid over time was evaluated by gender, it was observed that there was more increase in uric acid level in men than in women ( $p=0.034$, Table III).

\section{DISCUSSION}

Heart failure (HF) is defined as a structural or functional disorder that causes the heart to fail to supply enough oxygen to meet the metabolic needs of the tissues. ${ }^{1}$ In developed countries, it is found in approximately $1-2 \%$ of the society with $\mathrm{HF}$ and its prevalence increases with aging. ${ }^{8}$ Information about the prognosis of $\mathrm{HF}$ can be obtained from easily available data such as etiology, age, NYHA class, LVEF, important concomitant diseases (such as kidney dysfunction, diabetes, hyperuricemia, anemia) and plasma natriuretic peptide concentrations. However, apart from these, it can provide prognostic information in many variables. It is clear that these variables, and of course the prognosis, have changed over time. Prognosis assessment is particularly important when advising patients about left ventricular-assist devices and surgical treatment (transplantation) and when planning end-of-life care with patients' families and caregivers. Many biochemical parameters are used in the diagnosis of the disease, in the evaluation and followup of the response to treatment, and these may be of prognostic importance. Uric acid is the end-product that occurs as a result of purine metabolism in humans and its relationship with cardiovascular diseases has been studied in many studies. ${ }^{9,10}$ Uric acid has been shown to cause vascular inflammation and endothelial dysfunction by causing increased reactive oxygen radicals, the vascular smooth proliferation of muscle cells, and decreased production of nitric oxide. ${ }^{11}$ In human and animal experiments, reactive oxygen radicals caused by increased uric acid levels have been shown to impair myocardial function. ${ }^{12-14}$ Studies have suggested that there is a relationship between reduced ejection fraction and increased uric acid levels. ${ }^{15}$ Some authors argue that the increase in serum uric acid levels usually accompanies chronic heart failure and that there is a nearby relationship between the degree of heart failure and serum uric acid levels. They also stated that this relationship is independent of diuretic use and glomerular filtration rate. ${ }^{10,11}$ Piepoli et al. have demonstrated that serum uric acid levels are associated with increased mortality in patients with congestive heart failure. ${ }^{16}$ However, it is not yet clear whether uric acid is involved in the pathophysiology of heart failure or if its level increases secondary to heart failure.

This study showed that although the patients had an LVEF average below $40 \%$ in the last year before exitus, there was no progressive decrease in systolic function. At the same time, when patients in the same stage according to the NYHA stage were included, an increase in uric acid was observed over time, but LVEF was not an effective factor in this change $(p=0.327)$. The reason for this situation may be that uric acid increased in chronic heart failure causes endothelial dysfunction by causing oxidative stress in the endothelium. Moreover, the vasodilator response to exercise is significantly impaired and a vicious cycle of uric acid rises with increasing hypoxia at the tissue level with increased oxidative stress. ${ }^{17}$ Therefore, although the ejection fraction remains stable in patients with heart failure, an increase in uric acid can be expected over time. This study also showed that although LVEF was stable, there was an increase in uric acid levels in patients over time. There are differences in the effect of gender on left ventricular ejection fraction and prognosis in heart failure patients. ${ }^{18}$ The effect of serum uric acid levels on cardiovascular outcomes is more pronounced in the female gender, ${ }^{19}$ but the role of gender on survival has not yet been clearly determined. In the study conducted by Viera Stubnov et al., serum uric acid levels were reported to be an independent factor in all-cause death in women (HR $1.65 \% 95 \mathrm{Cl} 1.24-2.20, \mathrm{p}<0.001$ ), while there was no such risk factor in men (HR 1.06, 95\% Cl 0.89-1.25, $\mathrm{p}=0.527){ }^{20}$ Adenosine, locally synthesised in vascular smooth muscle in the heart, is rapidly converted into uric acid by the endothelium and released into the vascular lumen in the case of low intracellular $\mathrm{pH}$ and negative membrane potential. ${ }^{21}$ Especially in the 12th month, it is evident that the reason for the appearance of uric acid elevation is prominent tissue ischemia in pre-death terminal period.

However, the low number of female gender in this study was the limitation of the study. In this study, exitus in the last one year and the level of uric acid looked at during this period is significantly higher in women. However, the 
increase in uric acid in recent periods was more pronounced in men and was higher in men from the twelfth month.

\section{CONCLUSION}

The uric acid increase is an independent factor for mortality in patients with heart failure. Gender was evaluated as one of the factors affecting uric acid increase. Although high uric acid in women is evident in the initial period, the level of uric acid in men was found to be higher in the recent period. Further and more extensive studies are needed to evaluate this effect of gender.

\section{ETHICAL APPROVAL:}

This study was conducted in compliance with the ethical principles according to the Declaration of Helsinki, and it was approved by the local Institutional Review Board (Number: 2020/16).

\section{PATIENTS' CONSENT:}

Since it was designed as a retrospective study, the data were collected from the hospital archive after approval of the Ethics Committee.

\section{CONFLICT OF INTEREST:}

The authors declared no conflict of interest.

\section{AUTHORS' CONTRIBUTION:}

IA, MC: Conceived the study design, involved in data collection, performed the statistical analysis, interpreted data and prepared the manuscript draft.

All the authors critically reviewed the final version of the manuscript and approved the final version.

\section{REFERENCES}

1. Ponikowski P, Voors AA, Anker SD, Bueno H, Cleland J, Coats A, et al. 2016 ESC guidelines for the diagnosis and treatment of acute and chronic heart failure: The task force for the diagnosis and treatment of acute and chronic heart failure of the european society of cardiology (ESC) developed with the special contribution of the heart failure association (HFA) of the ESC. EurJ Heart Fail 2016; 18(8):891-975. doi: 10.1002/ejhf.592.

2. Samsky MD, Dunning A, DeVore AD, Schulte PJ, Starling RC, Tang W, et al. Liver function tests in patients with acute heart failure and associated outcomes: insights from ASCEND-HF. Eur J Heart Fail. 2016; 18(4):424-32. doi: 10.1002/ejhf.440.

3. Gravning J, Askevold ET, Nymo SH, Ueland T, Wikstrand J, McMurray JJ, et al. Prognostic effect of high-sensitive troponin T assessment in elderly patients with chronic heart failure: results from the CORONA trial. Circ Heart Fail 2014; 7(1):96-103.doi: 10.1161/CIRCHEARTFAILURE.113. 000450.

4. Simpson J, Jhund P, Lund LH, Padmanabhan S, Claggett BL, Shen $\mathrm{L}$, et al. Prognostic models derived in paradigm-HF and validated in atmosphere and the swedish heart failure registry to predict mortality and morbidity in chronic heart failure. JAMA Cardiology 2020; 5(4):432-41. doi: 10.1001/ jamacardio.2019.5850.

5. Yang Y, Lin LH, Gao M, Tang RN, Ma KL, Tu Y, et al. Association between the serum uric acid level and the severity of coronary artery disease in a retrospective study of china nondialysis CKD patients. Metab Syndr Relat Disord 2020; 18(4):206-11. doi: 10.1089/met.2019.0114.

6. Liu F, Du GL, Song N, Ma YT, Li XM, Gao XM, et al. Hyperuricemia and its association with adiposity and dyslipidemia in Northwest China: Results from cardiovascular risk survey in Xinjiang (CRS 2008-2012). Lipids Health Dis 2020; 19(1):58. doi: 10.1186/s12944- 020-01211-z.

7. Johnson RJ, Bakris GL, Borghi C, Chonchol MB, Feldman D, Lanaspa MA, et al. Hyperuricemia, acute and chronic kidney disease, hypertension, and cardiovascular disease: Report of a scientific workshop organized by the national kidney foundation. Am J Kidney Dis 2018; 71(6):851-65. doi: 10.1053/j.ajkd.2017.12.009.

8. Hao G, Wang X, Chen Z, Zhang L, Zhang Y, Wei B, et al. Prevalence of heart failure and left ventricular dysfunction in China: the China Hypertension Survey, 2012-2015. Eur J Heart Fail 2019; 21(11):1329-37. doi: 10.1002/ejhf.1629.

9. Konta T, Ichikawa K, Kawasaki R, Fujimoto S, Iseki K, Moriyama $T$, et al. Association between serum uric acid levels and mortality: A nationwide community-based cohort study. Sci Rep 2020; 10(1):6066. doi: 10.1038/ s41598-020-63134-0.

10. Maloberti A, Giannattasio C, Bombelli M, Desideri G, Cicero A, Muiesan ML, et al. Hyperuricemia and risk of cardiovascular outcomes: The experience of the urrah (Uric Acid Right for Heart Health) project. High Blood Press Cardiovasc Prev 2020;27(2):121-8. doi: 10.1007/ s40292-020-00368-Z.

11. Feig DI, Kang DH, Johnson RJ. Uric acid and cardiovascular risk. N Engl J Med 2008; 359(17):1811-21. doi: 10.1056/ NEJMra0800885.

12. Minhas KM, Saraiva RM, Schuleri KH, Lehrke S, Zheng M, Saliaris AP, et al. Xanthine oxidoreductase inhibition causes reverse remodeling in rats with dilated cardiomyopathy. Circ Res 2006; 98(2):271-9. doi: 10.1161/01.RES. 0000200181.59551 .71$.

13. Ponikowski P, Jankowska EA. Patogenia y presentacio'n clı́nica de la insuficiencia cardiaca aguda. Rev Esp Cardiol 2015; 68(4):331-7. doi.org/10.1016/j.recesp.2015.01.003

14. Ogino K, Kato M, Furuse $Y$, Kinugasa $Y$, Ishida K, Osaki S, et al. Uric acid-lowering treatment with benzbromarone in patients with heart failure: A double-blind placebo-controlled crossover preliminary study. Circ Heart Fail 2010; 3(1):73-81. doi: 10.1161/CIRCHEARTFAILURE.109. 86860.

15. Zhao L, Cao L, Zhao TY, Cao L, Zhao TY, Yang X, et al. Cardiovascular events in hyperuricemia population and a cardiovascular benefit-risk assessment of urate-lowering therapies: a systematic review and meta-analysis. Chin Med J (Engl) 2020; 133(8):982-93. doi: 10.1097/CM9. 0000000000000682.

16. Piepoli MF, Salvioni E, Corrà U, Doni F, Bonomi A, La Gioia R, et al. Increased serum uric acid level predicts poor prognosis in mildly severe chronic heart failure with reduced ejection fraction. An analysis from the MECKI score research group. Eur J Intern Med 2020; 72:47-52. doi: 10.1016/j.ejim.2019.11.003. 
17. Wray DW, Amann M, Richardson RS. Peripheral vascular function, oxygen delivery and utilization: The impact of oxidative stress in aging and heart failure with reduced ejection fraction. Heart Fail Rev 2017; 22(2):149-66. doi: 10.1007/s10741-016-9573-4.

18. Regitz-Zagrosek V, Seeland U. Sex and gender differences in myocardial hypertrophy and heart failure. Wien Med Wochenschr 2011; 161(5-6):109-16. doi: 10.1007/s10354011-0892-8.

19. Odden MC, Amadu AR, Smit E, Lo L, Peralta CA. Uric acid levels, kidney function, and cardiovascular mortality in US adults: National health and nutrition examination survey (NHANES) 1988-1994 and 1999-2002. Am J Kidney Dis 2014; 64(4):550-7. doi: 10.1053/j.ajkd.2014.04.024.

20. Stubnova V, Os I, Høieggen A, Solbu MD, Grundtvig M, Westheim AS, et al. Gender differences in association between uric acid and all-cause mortality in patients with chronic heart failure. BMC Cardiovasc Disord 2019; 19(1):4. doi: 10.1186/s12872-018-0989-8.

21. Kroll K, Bukowski TR, Schwartz LM, Knoepfler D, Bassingthwaighte JB. Capillary endothelial transport of uric acid in guinea pig heart. Am J Physiol 1992; 262(2 Pt 2):H420H431. doi: 10.1152/ajpheart.1992.262.2.H420. 